\title{
Post Operative Pain Management with Matrabasti (Enema with medicated oil) in Haemorrhoidectomy - A Case Study
}

\author{
Case Report
}

\section{Shivanand A Kembhavi1 ${ }^{*}$, Hemanth Toshikhane ${ }^{2}$}

1. PhD Scholar. 2. Dean faculty of Ayurveda, Parul Institute of Ayurveda, Parul University Vadodara, Gujarat. India.

\begin{abstract}
Post operative pain management is always a challenge for ano-rectal surgeons. Haemorrhoidectomy is often involved with severe post operative pain and discomfort during defecation. Ayurvedic surgeon most of the time depends of contemporary medical science and uses analgesics, which has its own adverse effects. Many times mere oral ayurvedic medicines are not sufficient to mange post operative pain. Basti (enema with medicines) is regarded as best treatment for vata dosh vitiation. Vata dosh vitiation is the main cause for the pain. In post operative wounds also, trauma and blood loss lead to vata vitiation and causes pain. There are different types of basti's explained in the classics. Matrabasti (enema with medicated oil) is a type of Sneha Basti which can be given in all seasons without any strict regimen of Diet. It is a procedure where a minimal quantity of medicated oil or medicated ghee is used in the form of enema. Post operative wound will aggravate vata and lead to pain. Hence matrabasti which is having minimal medicine is tried in post operative cases of haemorrhoidectomy. This increases time taken for the onset of pain after haemorrhoidectomy and also helps in easy evacuation of stools in post operative period.
\end{abstract}

Key Words: Haemorrhoidectomy, Ayurveda, Postoperative pain, Matrabasti.

\section{Introduction}

At least $50 \%$ of the people above the age of $50 y$ rs suffer with one or other complaints of haemorrhoids.(2). Haemorrhoidectomy surgery is the curative treatment for the haemorrhoids. This is indicated when all other treatment modalities fail. (3). Till now among all surgical procedures MilliganMorgan method is considered as gold standard surgical procedure (4). Post operative pain in haemorrhoidectomy always a challenging task for the surgeons. Ayurvedic surgeons always face problems while dealing with post operative pain management. Most of the time we depend upon contemporary medical science and use analgesics. Post operative pain in case of haemorrhoidectomy is so severe that it often makes patients to avoid surgery. A case of prolapsed thrombosed haemorrhoids was taken for the study and we tried Matrabasti using Chandanadi ropan tail $40 \mathrm{ml}$ to manage the post operative pain.

\section{Case Report}

A male patient aged 55 yrs presented on $9^{\text {th }}$ March 2020, with complaints of pain in the anal region,

\section{* Corresponding Author:}

Shivanand A Kembhavi

$\mathrm{Ph}$ D Scholar,

Parul Institute of Ayurveda

Parul University

Vadodara. Gujarat, India

Email Id: drshivanandk.sk@gmail.com mass per rectum, bleeding per rectum for 4 days. He has these complaints since many years and use to take treatment from local doctors. He used to feel better with medicines and mass was reducible earlier. This time mass was irreducible and more painful.

On per rectal examination it was diagnosed as prolapsed thrombosed haemorrhoids in all 3 positions 3 , 7 , and $11 \mathrm{O}$ clock positions. Patient was advised haemorrhoidectomy surgery. Written consent was taken for the surgery. All required investigations were done and were in normal limits.

\section{Diagnostics}

\begin{tabular}{|l|l|l|l|}
\hline \multicolumn{1}{|c|}{ Date } & \multicolumn{1}{c|}{ Type } & \multicolumn{1}{c|}{ Value } & \multicolumn{1}{c|}{ Unit } \\
\hline $2020-03-09$ & $\mathrm{Hb}$ (hemoglobin) & 14 & $\mathrm{~g} / \mathrm{dL}$ \\
\hline $2020-03-09$ & BP (blood pressure) & $130 / 80$ & $\mathrm{mmHg}$ \\
\hline $2020-03-09$ & Glucose & 130 & $\mathrm{mg} / \mathrm{dL}$ \\
\hline $2020-03-09$ & HIV & $\begin{array}{l}\text { Non } \\
\text { reactive }\end{array}$ & \\
\hline $2020-03-09$ & HbsAg & Negative & \\
\hline
\end{tabular}

\section{Procedure Details}

Patient came to S.S, Ayurvedic medical college hospital Haveri on $9^{\text {th }}$ Mar 2020, after all clinical examinations and investigations patient was admitted in the hospital. Patient was advised for haemorrhoidectomy under local anaesthesia and sedation. (5). Patient was posted for haemorrhoidectomy on $10^{\text {th }}$ Mar 2020. Patient was made to lie in lithotomy position on the operation table. Patient was given Inj. Calmpose $2 \mathrm{ml}$ diluted in $2 \mathrm{ml}$ of distilled water for injection through IV route. 
Injection Xylocaine 2\% with adrenaline was used for local infiltration. Milligan-Morgan method of haemorrhoidectomy was followed. Patient was having prolapsed haemorrhoids at 3,7 , and $11 \mathrm{O}$ clock positions. All the 3 pile masses were dissected and excised after transfixation with cotton thread at the base of the haemorrhoids (6). Soon after haemorrhoidectomy procedure, $40 \mathrm{ml}$ of Luke warm Chandanadi ropan tail was given in the farm of enema. Using $50 \mathrm{ml}$ syringe and red rubber catheter oil was pushed in the anal canal. A small pad dipped in same Chandanadi ropan tail was kept as pack in the anal canal. Haemorrhoidectomy procedure took 25 minutes time, surgery started at $10 \mathrm{am}$ and completed at 10.25am. After haemorrhoidectomy patient shifted to post operative ward. Patient was under observation for the onset of post operative pain.

- Heamorrhoidectomy started - 10 AM

- Heamorrhoidectomy completed at $-10.25 \mathrm{AM}$

- Matra Basti with Chandanadi Ropan Tail (40ml) given at - 10.25AM.

- Onset of post operative pain - 5.30PM

- Total time taken for the onset of post operative pain is -7 hours.

Generally, patients undergoing haemorrhoidectomy under local anaesthesia start feeling pain after 2 to 3 hours. In this case patient started feeling pain after 7 hours, i.e., at $5.30 \mathrm{pm}$. Patient complained the onset of moderate pain, but he was comfortable he was not in need of analgesics injections.

\section{Drug}

Chandanadiropan tail is medicated oil mentioned in Sushrut samhita (7) in the context of sadyovranachikitsa (chapter which deals with traumatic wounds) chapter. He mentions that this is best oil for the sadyo vrana, i,e Post operative wound. This tail (oil) contains ingredients as follows

- Chandan. (Santlum Album L.)

- Uthpahal. (Nymphaea stellata Willd.)

- Priyangu.(Callicarpa Macrophylla Vahl.)

- Padmaka (Prunus puddum Franch.)

- Haridra. (Curcuma longa L.)

- Yashtimadu (Glycyrrhiza glabra L.)

- Lodra. (Symplocos racemosa Roxb.)

- Ksheera. (Cow milk)

Most of these drugs are having pitta shamaka properties and thus helps in controlling inflammation at the wound site. This oil when used in the form of Matrabasti with minimal quantity $40 \mathrm{ml}$ and in Luke warm temperature it controls vata dosh also. Thus, we can control vata vitiation due surgical trauma and also pitta vitiation

This tail was prepared using tila tail ( Sesame oil) as the base at S.S.Ayurvedic medical college. Haveri Karnataka pharmacy and used for the study.

\section{Discussion}

As per principles Ayurveda pain is always due to vitiation of vata dosh. Vata dosh gets aggravated due to many reasons and ends up with pain in different pathological conditions. In post operative cases pain is due to surgical wound. Surgical trauma and the bleeding during surgery, vitiates vata dosh and leads to post operative pain. (8) Basti treatment is the ideal and the best treatment for vata disorders. Tail also is the best medicine to control vata dosh.

There are different types of basti explained in Ayurveda. Among them Matrabasti is one type of sneha basti. This can be used in many cases of vata vitiation without any specific contra indication.

In Matrabasti which is a sneha basti is advised in the management of sadyo vrana (post operative wound). (9). Here we use very minimal quantity of medicine which is administered through anal canal. It can be used in all type of the patients and does not require admission to the hospital. There are no specific contra indications for matra basti. So Matrabasti is selected to use in post operative cases for the pain management. Matra Basti helped in extending the time taken for the onset of post operative pain. Here both, the procedure matra basti and taila (oil) will help in reducing vitiated Vata and thus help in managing pain. It also helped in the easy evacuation of stools also. This reduced the usage of analgesics in hemorrhoidectomy cases. Thus, helped in preventing undesired well known adverse effect of these analgesics like gastric irritation and constipation.

The other oral medications given in this case were.

\begin{tabular}{|c|l|l|l|}
\hline Sl.no & $\begin{array}{l}\text { Name of the } \\
\text { drug }\end{array}$ & Dosage & Anupan \\
\hline 1 & $\begin{array}{l}\text { Triphala } \\
\text { guggulu }\end{array}$ & $\begin{array}{l}\text { 500mg Thrice } \\
\text { a day for 10 } \\
\text { days }\end{array}$ & $\begin{array}{l}\text { Warm } \\
\text { water }\end{array}$ \\
\hline 2 & Gandak rasayan & $\begin{array}{l}\text { 250mg Thrice } \\
\text { a day for 10 } \\
\text { days }\end{array}$ & $\begin{array}{l}\text { Warm } \\
\text { water }\end{array}$ \\
\hline 3 & $\begin{array}{l}\text { Avipattikar } \\
\text { choorna }\end{array}$ & $\begin{array}{l}\text { Half Tea } \\
\text { Spoon twice }\end{array}$ & $\begin{array}{l}\text { Warm } \\
\text { water }\end{array}$ \\
\hline 4 & $\begin{array}{l}\text { Chandanadi } \\
\text { Ropan tail }\end{array}$ & $\begin{array}{l}\text { External } \\
\text { application } \\
\text { after each } \\
\text { defecation }\end{array}$ & \\
\hline
\end{tabular}

\section{Conclusion}

Time taken for the onset of post operative pain after haemorrhoidectomy extended by 4 hours, i.e, pain started after $7 \mathrm{hrs}$ of the surgery, which is usually 2 to 3 hrs.

Bowel evacuation on the second post operative day was very smooth, along with the medicated oil which was given in the form of matrabasti, patient passed the stools without much trouble.

The study needs to be conducted over a greater number of cases to establish its efficacy in the post operative pain management of haemorrhoidectomy cases. This is in progress now.

\section{Reference}

1. Text Book Of Surgery; The Biological Basis of Modern Practice, $-15^{\text {th }}$ ed/(edited by) David C. Sabiston, Jr editor for basic surgical science, $\mathrm{H}$. 
Kim Lyerly. Published by W.B.SAUNDERS COMPANY. Volume1-pp-1186 pg no (1037).

2. Charúa L. Enefermedadhemorroidal. Med. Int. Mex. 2007;23:302-309. [Google Scholar]

3. Text Book Of Surgery; The Biological Basis of Modern Practice, $-15^{\text {th }}$ ed/(edited by) David C. Sabiston, Jr editor for basic surgical science, $\mathrm{H}$. Kim Lyerly. Published by W.B.SAUNDERS COMPANY. Volume1-pp-1186 pg no (1037).

4. Agbo S.P. Surgical management of hemorrhoids. J. Surg. Tech. Case Rep. 2011;3:68-75. [PMC free article] [PubMed] [Google Scholar]

5. Text Book Of Surgery; The Biological Basis of Modern Practice, $-15^{\text {th }}$ ed/(edited by) David C. Sabiston, Jr editor for basic surgical science, $\mathrm{H}$.
Kim Lyerly. Published by W.B.SAUNDERS COMPANY. Volume1-pp-1186 pg no (1037).

6. Text Book Of Surgery; The Biological Basis of Modern Practice, $-15^{\text {th }}$ ed/(edited by) David C. Sabiston, Jr editor for basic surgical science, $\mathrm{H}$. Kim Lyerly. Published by W.B.SAUNDERS COMPANY. Volume1-pp-1186 pg no (1037)

7. Sharma P V. Sushruta Samhita of Acharya Sushruta $7^{\text {th }}$ edition. Varanasi; Chaukhambha Orientalia publishers;2002. Page no .410.(824)

8. Sharma P V. Sushruta Samhita of Acharya Sushruta $7^{\text {th }}$ edition. Varanasi; Chaukhambha Orientalia publishers;2002. Page no .409.(824)

9. Sharma P V. Sushruta Samhita of Acharya Sushruta $7^{\text {th }}$ edition. Varanasi; Chaukhambha Orientalia publishers;2002. Page no .409.(824). 